\title{
LCP2 Gene
}

National Cancer Institute

\section{Source}

National Cancer Institute. LCP2 Gene. NCI Thesaurus. Code C24543.

This gene is involved in signal transduction. It plays a role in the activation and development of T cells. 